\title{
Cooperative Learning: Practices, Challenges and Its Implication for Quality Education in Undergraduate Regular Program of Wollo University
}

\author{
Bezabih Wondimu (PhD) \\ Department of Educational Planning and Management, College of Education and Behavioral Studies, Madda \\ walabu University, Bale-Robe/ Ethiopia \\ Arega Kassaw (Mr.) \\ Department of History and Cultural Heritage, College of Social Science \& Humanities, Wollo University, Dessie \\ Campus, Ethiopia
}

\begin{abstract}
The purpose of this study was to investigate the practices and challenges of cooperative learning and its implication for quality education in under graduate program of Wollo University, Dessie Campus. To achieve the purpose of the study, a concurrent triangulation research design was applied whereby collection and analysis of quantitative and qualitative data were undertaken at the same time in an integrated manner. The target populations for this study were students and instructors of Wollo University. From the total population of the study, 136 instructors and 346 students were taken as samples of the study. In addition, ten instructor informants were selected and interviewed. Moreover, three lesson observations were conducted by the writers. Thus, the instruments of data collection used for this study were questionnaire, interview, observation and document analysis. The data collected through questionnaire (quantitative data) were analyzed using frequency, percentage mean, standard deviation and independent sample t-test through SPSS 25.0. The finding of the study revealed that the implementation of cooperative learning in Wollo University is not satisfactory. It becomes evident that the characterizing features of good implementation of cooperative learning were not effectively practiced in the University. Furthermore, the finding of the study indicated that the benefits that students acquired due to the implementation of cooperative learning are not encouraging. The study also identified the challenges that hindered implementation of cooperative learning. From the findings of the study, awareness creation training about the practices and principles of cooperative learning was recommended as a recommendation of the study.
\end{abstract}

Keywords: Cooperative Learning, Practices, Challenges, Quality education

DOI: $10.7176 / \mathrm{JEP} / 10-31-06$

Publication date: November $30^{\text {th }} 2019$

\section{Orientation of the Study}

\section{Background of the Study}

Teaching methods vary with the extent to which they involve the learners or with the roles the students and teachers assume during the teaching and learning process. At one end, there is a teacher dominated method which involves the most direct way of transmitting knowledge to the learners. Here learners are considered as passive listeners. What is expected from them is to absorb simply what is said by the teacher and this is often labeled as the traditional or the teacher-centered method. According to Hagos (2012), in this method the teacher use "chalk and talk" or the teacher is active and the students passively copy the notes in their exercise book or memorize the information from their text books.

The notion of learner-centered education, on the other hand, views learning as a collaborative process between teachers and learners. One such approach which views learning as a collaborative effort is cooperative learning. Until the mid-1960s, cooperative learning was relatively unfamiliar and largely ignored by educators because individual learning was mainly focused in teaching at that time (Xuan, 2015). However, from the 1970s, cooperative learning has been seen as an acceptable instructional approach for all level of education, all parts of the world and every age group.

Cooperative learning is a student-centered method, in which learners work in pairs or in a small group on a project or a task to achieve a common goal through helping each other. It is the pedagogical use of small groups in which students with various ability, gender, nationalities and different level of social skills work together in such a way that they all strive to attain a common goal and in a situation that all group members feel responsible for their individual learning and also for all group members' learning (Johnson, Johnson\& Smith, 1998).

Cooperative learning as a pedagogical strategy has been widely researched since its establishment in the 1970 s and it is often advocated as an effective classroom practice (Hennessey, 2013). Cooperative learning refers to a variety of cooperative learning methods (such as Student Team-Achievement Division, Learning Together, Jigsaw, Three-Step Interview, Teams-Games-Tournaments and Number Heads) in which students work in small 
groups to help one another learn academic content.

In supporting these viable ideas, Neo (2005) suggests that effective cooperative learning environment allows for in-depth conversation, discussion, debate and relationship-building among the students in groups, encouraging them to work well together as a team. Students working cooperatively will work through the assignments until all group members successfully understand and complete it.

Modern universities are facing challenges due to the increasing number of young people attending higher education. The sheer number of students raises the question of how to organize teaching-learning activities that allow the students to become active learners and engaged participants in academic discussions within their disciplines rather than passive audience. In addition, the mass university faces a heterogeneous student body. Many of these students, motivated by career opportunities or other external motivation, might need situational motivation to engage in deep levels of learning that are necessary to reach the necessary deep level of understanding of the often complex phenomena studied at the university level. Within the last decade, 'student-centered' instructional methods have become increasingly popular in higher education, and one such method is cooperative learning.

Without denying the significance of traditional lectures and instructor-led discussions in undergraduate education, an increasing number of teachers are recognizing the value of also assigning collaborative work to their students. Small group work, used both in and out of class, can be an important supplement to lectures, helping students master concepts and apply them to situations calling for complex applications of critical thinking skills (Neo, 2005).

Because of its success, cooperative learning began to be adopted by different countries. Its core principles are also widely accepted and began to be practiced. Ethiopia, like many other developing countries, embraced cooperative learning as a tool to improve the quality of education. An attempt has been made to implement cooperative learning since 1994 and designed a New Educational and Training Policy which introduced changes in the implementation of educational activities (Alamawum, 2014). Thus, universities of the country are attempting to implement cooperative learning to uplift students' learning opportunity. Even though the science of pedagogy promotes cooperative learning as one of the good strategies that maximize students' advancement in academic, social, and personal development by working together, its practical implementation is accompanied with several challenges.

Like other universities of the country, Wollo University is implementing the cooperative learning method. It has acknowledged the significance of cooperative learning strategies to improve students' learning opportunities. However, there are evidences that show that cooperative learning in the University is facing with different challenges. Thus, I intend to investigate the practices and challenges of cooperative learning in Wollo University, Dessie Campus.

\section{Statement of the Problem}

The traditional teacher-centered teaching method often created classroom atmospheres in which learners competed with each other. The traditional model has fostered competition rather than cooperation which is favored by the major students. Educators also believe that minority students might fall behind higher achieving students in the traditional models of competitive learning. Traditional instructions such as lectures, explanations and answerquestion routines focus exclusively on individual academic goals. Today, educationalists' opinions about effective teaching have shifted from teacher-centered to learner-centered. One of the student-centered educational approaches is cooperative learning (Yeabsira, 2015).

According to Muhammed (2014), the challenge in education today is to effectively teach students of diverse ability and differing rates of learning. Therefore, Universities are adapting different strategies to improve students' learning that will in turn contribute to the development of wider societies. Cooperative learning is one of those approaches that have been adopted long ago and still implementing in higher education since it has diversified advantages for students. Cooperative learning strategies enhances students' cognitive development and social development such as knowledge building, meta-cognition, self-esteem and positive peer relationship. Therefore, current emphases given for cooperative learning increases since it has multiple advantages for students.

In the Ethiopian context, there are different researches conducted on cooperative learning. However, the focus of most of these researches is either on primary and secondary schools, or English language. For example, Alamawum (2014) tried to evaluate the design of the speaking lessons in Grade 11 English Textbook in terms of Promoting Cooperative Learning, focusing on Jigjiga Preparatory School. Hanna (2015) assessed teachers' and students' attitudes towards cooperative learning in selected primary schools in Bole Sub City. Yeabsira (2015) tried to examine problems affecting the implementation of cooperative learning in primary schools. Aragaw (2015) explored the Effect of Cooperative Learning on Students' English as a Foreign Language (EFL) Reading Comprehension: Meshentie Grade Nine High School Students in Focus.

There have been little researches done on cooperative learning on Ethiopian Universities. Muhammed (2014) conducted a research on Cooperative Learning Practices in College of Education and Behavioral Sciences in Haramaya University. Thus, his research is limited to a single college in Haramaya University. Since the scope of 
his study was delimited only to one college, the results of his study may not be generalized to Haramaya University let alone other universities of the country. In addition, rather than treating both practices and challenges of cooperative learning, his work has emphasized on the former. Efrem Gulfo and Oukula Obsa (2015) attempted to investigate students' attitude towards One-to-Five cooperative learning in Wolaita Sodo University. But they did not incorporate teachers' attitude towards cooperative learning.

Based on the studies made so far, it is possible to say that no one has addressed the present study directly in similar scope and objectives, at least to the knowledge of the writers. Thus, the present study is different from all aforementioned studies in the following respects. Firstly, the previous researches were conducted in other areas than the current study area; and as to our knowledge there is no research conducted under a similar topic in the current study area, that is., Wollo University. Secondly, most of these researches focused on primary and secondary education levels, and on English language classes. The current study is different in this respect because it is conducted on one of the tertiary level institutions (universities) of our country. Thirdly, in terms of scope, the current study is wider than those previous researches conducted on cooperative learning in Ethiopian higher educational institutions. From this, it is possible to conclude that there is a research gap filled by this study.

All the aforementioned research gaps together with our observation of the problem triggered us to conduct the research on practices and challenges of cooperative learning. Hence, this study assessed the practices and challenges in implementing cooperative learning in Wollo University. Hence, in order to address, the gabs of the study in concrete term, the following basic research questions were raised and answered in the course of the study.

1. What are the practical activities done by students and instructors of the University to implement cooperative learning strategies?

2. What are the benefits students gained due to the implementation of cooperative learning?

3. What are the challenges that students and instructors of the University face while practicing cooperative learning?

\section{Delimitation of the Study}

The need to investigate practices and challenges of cooperative learning may require wider coverage of population by including other universities of the country. However, due to time and resource constraints this study is limited to Wollo University, Dessie Campus. It is also important to delimit the variables to be treated in this study. Since the study attempted to investigate the practices and challenges of cooperative learning in the study area, the dependent variable of the study is effectiveness of cooperative learning; whereas, the independent variables are practices and challenges of cooperative learning. Under practices of cooperative learning, issues treated are positive interdependence, face-to-face interaction, individual and group responsibility, social skills, and group processing. The independent variables for challenges of cooperative learning are social skills of students, attitude/perception of student and instructors, availability of resources, class size, and methods applied in group formation were taken as focus areas of the study.

\section{Theoretical framework of the Study}

Some of the greatest theorists of the $20^{\text {th }}$ century have focused on cooperation. The use of cooperative learning in college classes has its roots in the creation of social interdependence and cognitive-developmental learning theories. Cognitive-developmental theory views cooperation as an essential prerequisite for cognitive growth. Piaget's ideas have been widely interpreted as supporting the creation of classroom environments where students play active roles as they engage in real or at least realistic tasks (Wang, 2009).

The other theory works in the cooperative learning is the theory of social constructivism which believed that child's mind is inherently social in nature and so speech moves from communicative social to inner egocentric. Vygotsky considers cognitive development primarily as a function of external factors such as cultural, historical, and social interaction rather than of individual construction. He states that cognitive growth occurs first on a social level, and then it can occur within the individual. To make sense of others and construct knowledge on such a social level allow learners to relate themselves to circumstances (Amineh \& Asl, 2015). Social constructivists emphasize that learning is active, contextual and social; therefore the best method is 'group-learning' where teacher is a facilitator and guide. In contrast to traditional classrooms where teachers used a linear model and oneway communication, the modern learning is becoming more personalized, student-centric, nonlinear and learnerdirected (Blake \& Pope, 2008).

The theories of Vygotsky and Piaget complimented each other. The former advocated social interaction in learning while the latter promoted active learning of the learners. Both were essential elements in the realization of cooperative learning in real life classroom. Neither theory alone was able to provide a complete explanation for the implementation of cooperative learning. Being student-centered by nature, cooperative learning owed much credit to constructivism. Constructivism, or constructivist approach, was not a brand new theory but a holistic approach to the teaching and learning process developed by incorporating concepts from Piaget, Vygotsky, and Bandura (Liang, 2002). 
From the above discussions on theories related to cooperative learning, Vygotsky's social constructivism seems more appropriate theory for the proposed study. It is because cooperative learning requires students to learn through social interaction with their classmates which help student to construct knowledge. Cooperative learning requires students to interact each other for improving their academic achievement, and social constructivism also supports construction of knowledge by students through social interaction. This makes the theory preferable for this study.

\section{Conceptual Framework of the Study}

The writers have developed the conceptual framework for this study. Cooperative learning is the dependent variable whereas practices of cooperative learning and challenges of cooperative learning are the independent variables of the study. A successful implementation of cooperative learning depends up on the extent to which elements of cooperative learning are applied. Thus the five elements of cooperative learning are the independent variables of practices of cooperative learning. Students' and instructors' efforts were assessed to investigate the practices of cooperative learning in the University. The independent variables of challenges of cooperative learning include variables such as class size, perception towards cooperative learning, organization of the curricular material, group composition and resources. Hence, the following figure is believed to properly show the conceptual framework of the study.

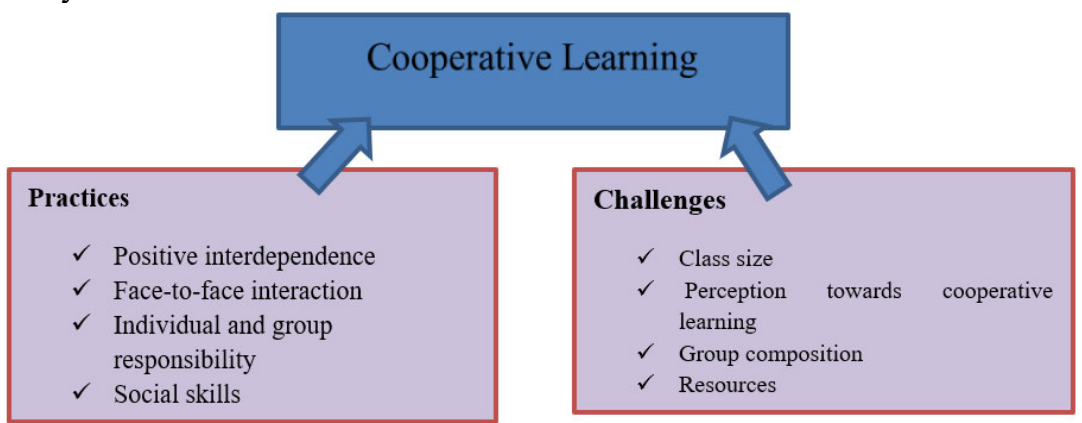

Figure 1: Graphical representation of conceptual framework of the study

As stated above the independent variables are practices of cooperative learning which incorporate the five elements (positive interdependence, face-to-face interaction, individual and group responsibility, social skills and group processing) and challenges of cooperative learning such as class size, group composition and resources. Using different literature, these variables are elaborated as follows.

\section{Research Design and Methods}

Paradigm Used for the Study

Based on the purpose of the study and basic research questions, pragmatism was selected as the appropriate research paradigm for this study. It is because of the fact that this paradigm provides an opportunity to use different research methods, different forms of data collection and analysis in applying mixed research method (Creswell, 2014).

\section{Research Methods}

Research can be defined as a systematic and methodical process that investigates a phenomenon, addresses an issue, answers a particular question and solves problems, all of which help increase existing knowledge. In line with this, a mixed approach, that is, combination of both qualitative and quantitative methods of data collection and analysis were used. More specifically, concurrent/triangulation design where collection and analysis of quantitative and qualitative data is taken place at the same time to best understanding of the research problem was used. This method enables to investigate the current practice and challenges of cooperative learning in the University.

\section{Sources and Types of Data}

Both primary and secondary data sources were used to gather pertinent data for the study. The primary sources of data were instructors and students of Wollo University. Secondary data is obtained from documents such as reports, manual prepared by the University.

\section{Target Population, Samples and Sampling Procedures Target Population}

The study populations in this research were students and instructors of Wollo University. Currently, there are about 7,031 undergraduate regular students and 537 on-duty instructors only in Dessie Campus, which in turn used as a 
population of the study.

\section{Sampling and sampling techniques of the Study}

As mentioned in the outset of the study, the focus of this study was to investigate the practices and challenges of cooperative learning. Taking the whole populations as a target is costly and time consuming. In addition, the writers believe that these members of the university community can provide relevant information to understand the problem under consideration. To give equal chances and have good representative samples who fill the questionnaires, stratified random sampling was employed. In addition, purposive sampling technique was employed to get respondents for the interview. In Wollo University (Dessie Campus), there are eight colleges and fifty-one departments. For this study, the colleges were stratified into two categories under Social Science and Natural Science fields. Accordingly, the colleges grouped under the category of Natural Science are veterinary, health, agriculture and natural science. The colleges under Social Science are law, social science and humanities, pedagogy and behavioral science, and business and economics. From each stratum, two colleges were randomly selected.

Based on the above procedure, social science and Humanities College, and school of law are selected from the Social Science stratum; and natural science and agriculture from the Natural Science stratum. The total number of students and instructors of the four colleges/school is 3093 and 277 respectively. Using Yemane's (1967) sample size determination formula which is appropriate to determine sample size from a large population, the sample size for this study is computed as follows:

Where: $\quad \mathrm{n}=$ required sample size

$$
n=\frac{N}{1+N e^{2}}
$$

$\mathrm{N}=$ the size of population

$\mathrm{e}=$ margin of error at $5 \%$ (the standard value is 0.05$)$

Thus, the students' sample size is calculated as follows.

$$
\begin{aligned}
n=\frac{3092}{1+(3092)(0.05)^{2}}=\frac{3092}{1+(3092)(0.0025)} & =\frac{3092}{1+7.73}=\frac{3092}{8.73}=\frac{3092}{1+7.73} \\
\mathbf{n} & =\mathbf{3 5 4}
\end{aligned}
$$

Thus, out of 3,093 students of the university, 354 sample students were selected to fill the questionnaire. Adding, in order to determine the sample size of instructors, the writers preferred to use table formula method because unlike the students, the population for instructors is small, that is 277 . Thus, out of 277 instructors, 151 of them were made participants of the study.

\section{Instruments of Data Collection}

In order to obtain valuable information about the practices and challenges of cooperative learning, data were collected from students and instructors of the University through questionnaire, interview and observation, as well as from documents.

\section{Validity and Reliability of the Instruments Validity}

Validity is defined as the extent to which the instrument measures what it purports to measure. To maintain validity, the data collection instruments were commented by scholars who have research experiences. In addition, triangulations of data collection instruments were made. As mentioned above, questionnaires, interview, observation and document review were employed to collect data for the study.

\section{Reliability}

Reliability refers to consistence of the findings of the study. To determine the reliability of the data collection instruments, Cronbach's Alpha internal consistency was used. If the items in a test are correlated to each other, the value of alpha is increased. An acceptable alpha value range between 0.70 and 0.90 (Tavakol, 2011). The reliability of the instruments is assured with the help of pilot testing by taking $5 \%$ of the size of sample respondents that is 25. The respondents on whom the questionnaire was tested were excluded from being sampled respondents for the main study. 
Table-1: Cronbach's Alpha computed to check reliability of items

1 Positive interdependence

2 Individual accountability

9

Face to face interaction

Social interaction

Group processing

Challenges of cooperative learning

Benefits of cooperative learning

\section{(}

Cronbach's Alpha

The above table shows Cronbach's Alpha, which is computed to check the reliability of items used to collect data through questionnaire. As can be seen in the table, Cronbach's Alpha value computed using SPSS for all of the seven items is by far greater than 0.70 . Thus, the items fulfilled the requirements of internal consistency, which ensure reliability of the data collection instruments.

\section{Methods of Data Analysis}

The data gathered through questionnaire and interview was analyzed quantitatively and qualitatively respectively. The quantitative data that were gained from different respondents using questionnaire was organized, tabulated and analyzed through frequency, percentage, mean, standard deviation and independent t-test using SPSS of version 25.0. Frequency, percentage, mean, and standard deviation were used to explain the extent to which cooperative learning is practiced in the university, the challenges faced, and benefits gained because of the implementation of cooperative learning. Independent sample t-test was also used to measure the statistical significance of the mean values of instructor and student respondents for the elements of cooperative learning (positive interdependence, individual accountability, face to face interaction, social interaction, group processing), challenges and benefits of cooperative learning. The data that was collected through interview, open ended questions, and secondary data were analyzed using thematic or grouping similar idea together and narrating the summarized descriptions of the subject of the study. Based on the data analysis, interpretations were made to reach at certain findings.

\section{Data Analysis and Interpretation}

\section{Practices of Cooperative Learning}

This part of the study focused on the practices of cooperative learning and it attempts to assess the implementation activities of this learning method in the University. Based on the data collected through questionnaire, interview, observation, and document analysis, the implementation of the four elements of cooperative learning are discussed as follows. For the data collected through questionnaire, respondents were required to respond the items by saying "strongly agree", "agree", "undecided", "disagree" or "strongly disagree" with 5, 4, 3, 2, 1 scores respectively. Note that the range of mean values for these five scale responses is specified as $<1.5$ 'strongly disagree', $\geq 1.5$ to $\leq 2.5$ 'disagree', $>2.5$ to $\leq 3$ 'undecided', $>3$ to $\leq 4$ 'agree' and $>4$ 'strongly agree'.

\section{i. $\quad$ Positive Interdependence}

Table-4: Instructors' and Students' Response on "Positive Interdependence” (n=136 for instructors and 346 for students)

\begin{tabular}{|c|c|c|c|c|c|c|c|c|c|c|c|c|c|c|c|c|}
\hline \multirow{3}{*}{\multicolumn{2}{|c|}{ Items }} & \multicolumn{15}{|c|}{ Response } \\
\hline & & \multicolumn{7}{|c|}{ Instructors } & & \multicolumn{7}{|c|}{ Students } \\
\hline & & & $\begin{array}{c}\text { Strongly } \\
\text { Agree }\end{array}$ & Agree & Undecided & Disagree & $\begin{array}{l}\text { Strongly } \\
\text { Disaggree }\end{array}$ & Mean & St.Dev & $\begin{array}{c}\begin{array}{c}\text { Strongly } \\
\text { Agree }\end{array}\end{array}$ & Agree & Undecided & Disagree & $\begin{array}{l}\text { Strongly } \\
\text { Disagare }\end{array}$ & Mean & St.Dev \\
\hline \multirow{2}{*}{\multicolumn{2}{|c|}{$\begin{array}{l}\text { All group members cooperate in learning activities } \\
\text { and are tesponsible for the success of failure of } \\
\text { each member in their group }\end{array}$}} & $F$ & 2 & 24 & 3 & 103 & 4 & \multirow[t]{2}{*}{2.39} & \multirow[t]{2}{*}{0.86} & 16 & 29 & 11 & 268 & 21 & \multirow[t]{2}{*}{2.28} & \multirow[t]{2}{*}{0.88} \\
\hline & & $\%$ & 1.47 & 17.65 & 2.21 & 75.74 & 2.94 & & & 4.64 & 8.41 & 3.19 & 77.67 & 6.09 & & \\
\hline \multirow{2}{*}{\multicolumn{2}{|c|}{$\begin{array}{l}\text { Students in a group share materials/resources to } \\
\text { accomplish takss while working in a group for a } \\
\text { common goal. }\end{array}$}} & $\mathbf{F}$ & - & 38 & 71 & 22 & 5 & \multirow[t]{2}{*}{3.04} & \multirow[t]{2}{*}{0.77} & ${ }^{63}$ & 278 & - & 5 & - & \multirow[t]{2}{*}{4.15} & \multirow[t]{2}{*}{0.47} \\
\hline & & $\%$ & & 27.94 & 52.21 & 16.18 & 3.67 & & & 18.21 & 80.34 & - & 1.45 & - & & \\
\hline \multirow{2}{*}{\multicolumn{2}{|c|}{$\begin{array}{l}\text { Students tutor each other until each group member } \\
\text { understands the material }\end{array}$}} & F & 7 & 58 & 36 & 33 & 2 & \multirow[t]{2}{*}{3.26} & \multirow[t]{2}{*}{0.94} & 2 & 83 & 14 & 199 & 48 & \multirow[t]{2}{*}{2.40} & \multirow[t]{2}{*}{1.02} \\
\hline & & $\%$ & 5.15 & 42.65 & 26.47 & 24.26 & 1.47 & & & 0.58 & 23.99 & 4.04 & 57.52 & 13.87 & & \\
\hline \multirow{2}{*}{\multicolumn{2}{|c|}{$\begin{array}{l}\text { Instructors organize groups based on heterogenencity } \\
\text { of students such as academic performance and sex } \\
\text { to enhance positive interdependence }\end{array}$}} & $F$ & 12 & 59 & 28 & 37 & - & \multirow[t]{2}{*}{3.34} & \multirow[t]{2}{*}{0.98} & 49 & 218 & 34 & 40 & 5 & \multirow[t]{2}{*}{3.77} & \multirow[t]{2}{*}{0.88} \\
\hline & & $\%$ & 8.82 & 43.38 & 20.59 & 27.21 & - & & & 14.16 & 63.01 & 9.83 & 11.56 & 1.44 & & \\
\hline & Aggregate mean & Instru & & & & & & 3.01 & .88 & Students & & & & & 3.15 & .81 \\
\hline
\end{tabular}

In item 1 of table 2, respondents were asked where or not cooperation of all group members in learning activities and taking responsibility for the success or failure of each member in their group. Accordingly the mean values of the instructor and student respondents are 2.39 and 2.28 respectively which implies both of the group of respondents disagreed. The standard deviation of the respondents is also less than one that indicates greater concentration of responses around the mean values. 
In item 2 of the same table, respondents were asked to indicate their views where or not students in a group share material/resources to accomplish tasks while working in a group for a common goal. Accordingly, the mean values (3.04 for the instructor and 4.15 for the students) of the two group of respondents confirm their responses of 'agree'. Similarly, the standard deviation for instructor and student respondents is small which is 0.77 and 0.47 respectively. Therefore, it seems instructor and students respondents showed agreement regarding the sharing of resources by group members.

Item 3 of table 2 focuses on identifying the willingness of students to tutor each other until each group member understands the material. From the response of respondents the mean values of the instructor and student respondents is 3.26 (nearly equivalent to agree) and 2.40 (represents disagree) respectively. The standard deviation is 0.94 for the instructors and 1.02 for the students which suggests better concentration of responses around the mean values.

Moreover, some of the student respondents explained in the open-ended question that they assumed tutoring other group members consumes their time thus they are not willing to provide such unreserved assistance. During the observation conducted to collect data for the study, the writers were able to confirm the reflection made by the majority of the respondents. From this, it can be said that there is a great gap among students to tutor each other until each member of their group understands the material.

In item 4 of table 2, respondents were asked to reply whether instructors organize groups based on heterogeneity of students such as academic performance and sex to enhance positive interdependence. Accordingly, majority of the response of the respondents' inclined to 'agree' is also supported with the instructor and student mean values of 3.34 and 3.77. The standard deviation of instructors and students is 0.98 and 0.88 which suggests strong concentration of responses around the mean values.

The writers' personal observation also ensures the fact that students were given challenging questions that could create an atmosphere of good group discussion though many of the students were passive in the group discussions. Based on this data, one can conclude that instructors usually give questions that are challenging and inviting all group members for hot discussion and debates.

Generally speaking the aggregate mean values for all items were found out to be 3.01 at standard deviation of 0.88 for teachers and 3.15 at standard deviation of .81 for students, which clearly showed that the practices of cooperative learning created positive interdependence among the teachers and students, where the findings of the study coincides with the views of Wang (2009), which states that cooperative learning is a tools for creating positive interdependence among students and teachers in the classroom teaching and learning processes.

\section{ii. Individual Accountability}

Table-3: Instructors' and Students' Response on "Individual Accountability" ( $\mathrm{n}=136$ for instructors and 346 for students)

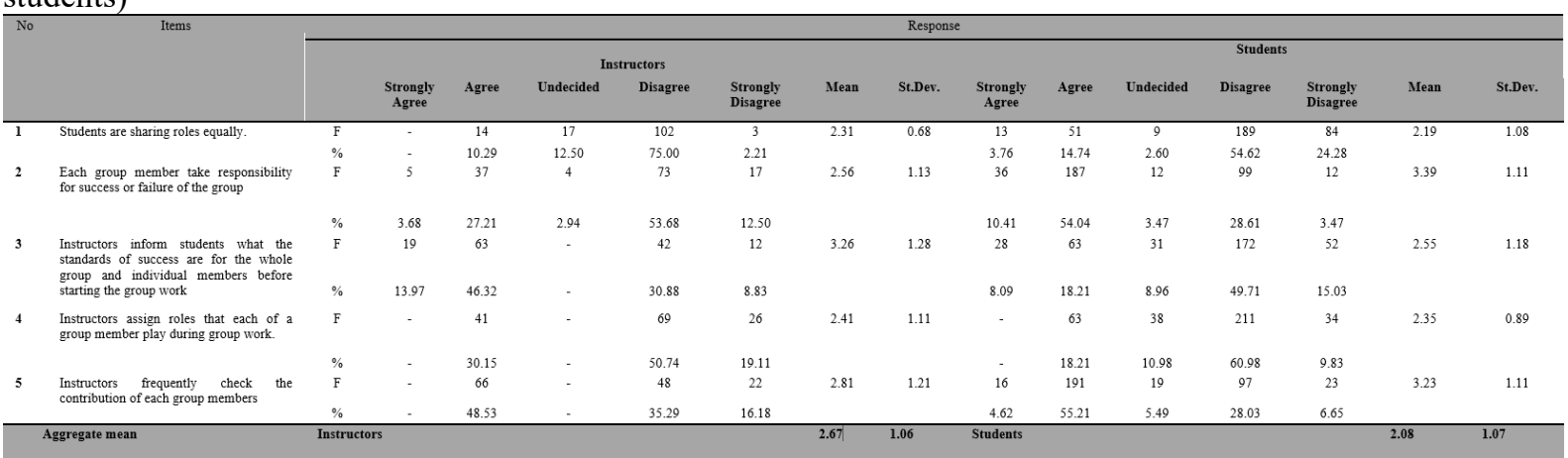

In table 3 the first item requires respondents to reflect their opinion if students in their group share roles equally. In line with this, the mean value 2.31 and 2.19 of the instructors and students respectively implies that respondents disagree about equal sharing of roles. As the standard deviation 0.68 of instructor responses is small, it suggests greater concentration of responses to disagree than the standard deviation 1.08 of the student responses.

In addition, some of the respondents who wrote their feeling about the issue made clear that most of the roles in cooperative learning are imposed on some of the group members, particularly the group leader, which is a great burden for them. Furthermore, some of my informants stated that they received complaints from group leaders claiming that group works specifically working group assignments was totally left to the group leader since other members of the group were unwilling to accomplish their roles. Thus, as can be seen from this data, most of the time students do not share role equally in working together in their respective groups.

The second item demands respondents to identify that each group member take responsibility for the success or failure of their group. For this item, the mean values of the instructor and student respondents are 2.56 and 3.39 with standard deviation of 1.13 and 1.11 respectively. Although the mean value of the instructors and students were found within the range of 'disagree and agree respectively, it is also very near to 'disagree' and the large standard deviation does not indicate concentration of responses around 'undecided' consequently it supports the 
response of 'disagree'. Despite this difference between the two groups of respondents, informants clarified that majority of the group members do not feel responsible for the success or failure of their group. Based on the evidences gained from respondents of the questionnaire and informants, we can state that many of the students do not take responsibility for the success or failure of their group.

Item three of the above table states that "instructors inform students what the standards of success are for the whole group and individual members before starting the group work." As indicated in the table, the mean values 3.26 and 2.55 of instructor and student respondents implies they agreed and disagreed respectively, which support the responses of the majority respondents. Since the standard deviation 1.28 is high that shows less concentration of instructor responses around the mean and the frequency is below half of the total instructor respondents, it seems even difficult to recognize the mean value as it is.

Based on the data described above, there is clear difference between instructor and student respondents whereby large number of instructor respondents claimed that they pre-informed their students about the success expected from the whole group and individual members when instructors provided group work; whereas nearly half of the student respondents reflected that their instructors did not inform students what the standards of success are for the whole group and individual members before starting the group work. However, the writers were able to observe that instructors did not pre-inform the standard of success expected from groups particularly during group discussions. Thus, it is possible to conclude that there was a gap among many of the instructors to inform groups the standard to be considered during cooperative learning.

In item 4 respondents were asked to indicate their views whether or not instructors assign roles that each of a group member play during group work. For this statement, majority of both student and instructor respondents disagreed which is also supported by the mean values 2.41 and 2.35 of the instructor and student respondents respectively. This indicate that instructors rarely assign role for each member of a group in conducting group work.

The last item of table 3 requests respondents to reflect their stand if instructors frequently check the contribution of each group member. Accordingly nearly half of the instructor respondents with mean value of 3.2 3 and majority of the student respondents agreed and the mean value 2.81 of the instructor respondents is nearer to agree, it seems reasonable to confirm the agreement of the respondents.

The data gained both form informants and the researcher's observation ensure that instructors frequently check the contribution of each group member particularly during group discussions. Of course, the informants implicitly mentioned that instructors do not usually follow up the contribution of each group member in cooperative learning activities such as working group assignments. Based on this data, it could be concluded that many of the instructors frequently check the contribution of each group member specifically during group discussions.

Generally speaking the aggregate mean values for all items were found out to be 2.67 at standard deviation of 1.06 for teachers and 2.08 at standard deviation of 1.07 for students, which clearly showed that the practices of cooperative learning failed to created individual accountability among the teachers and students, where the findings of the study contradicts with the views of Johnson (1998), which states that cooperative learning is a means for creating individual accountability among students and teachers in the classroom teaching and learning processes. 


\section{iii. $\quad$ Face to Face Interaction}

Table-4: Instructors' and Students' Response on "Face to Face Interaction" (n=136 for instructors and 346 for students)

\begin{tabular}{|c|c|c|c|c|c|c|c|c|c|c|c|c|c|c|c|c|}
\hline \multirow[t]{3}{*}{ No } & \multirow[t]{3}{*}{ Items } & \multicolumn{15}{|c|}{ Response } \\
\hline & & \multicolumn{7}{|c|}{ Instructors } & & \multicolumn{7}{|c|}{ Students } \\
\hline & & & $\begin{array}{l}\text { Strongly } \\
\text { Agree }\end{array}$ & Agree & Undecided & Disagree & $\begin{array}{l}\text { Strongly } \\
\text { Disagree }\end{array}$ & Mean & St.Dev. & $\begin{array}{l}\text { Strongly } \\
\text { Agree }\end{array}$ & Agree & Undecided & Disagree & $\begin{array}{l}\text { Strongly } \\
\text { Disagree }\end{array}$ & Mean & $\begin{array}{l}\text { St.De } \\
\text { v. }\end{array}$ \\
\hline \multirow[t]{2}{*}{1} & \multirow{4}{*}{$\begin{array}{l}\text { Students in a group freely } \\
\text { share their views, ideas and } \\
\text { feelings } \\
\text { Students challenge each } \\
\text { other's ideas and decisions }\end{array}$} & $\mathrm{F}$ & 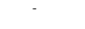 & 38 & 19 & 58 & 21 & 2.54 & 1.06 & 8 & 59 & 26 & 166 & 87 & 2.23 & 1.08 \\
\hline & & $\%$ & - & 27.93 & 13.96 & 42.67 & 15.44 & & & 2.31 & 17.05 & 7.52 & 47.98 & 25.14 & & \\
\hline \multirow[t]{2}{*}{2} & & $\mathrm{~F}$ & 16 & 52 & 3 & 63 & 2 & 3.13 & 1.17 & 17 & 54 & 11 & 203 & 61 & 2.32 & 1.09 \\
\hline & & $\%$ & 11.76 & 3824 & 2.21 & 4632 & 1.47 & & & 4.01 & 15.61 & 3.18 & 58.67 & 17.63 & & \\
\hline \multirow[t]{2}{*}{3} & \multirow{4}{*}{$\begin{array}{l}\text { Studcnts provide cach othcr } \\
\text { with effective and efficient } \\
\text { help while working in a } \\
\text { group. } \\
\text { Instructors encourage } \\
\text { students to actively engage in } \\
\text { group discussions }\end{array}$} & $\Gamma$ & 4 & 48 & 1 & 71 & 12 & 2.71 & 1.13 & 8 & ${ }^{73}$ & 19 & 216 & 30 & 2.46 & 0.00 \\
\hline & & $\%$ & 2.94 & 35.29 & 0.74 & 52.21 & 8.82 & & & 2.31 & 21.10 & 5.49 & 62.43 & 8.67 & & \\
\hline \multirow[t]{2}{*}{4} & & $\mathrm{~F}$ & 36 & 89 & - & 11 & & 4.10 & 0.76 & 24 & 201 & 37 & 45 & 39 & 3,36 & 1.15 \\
\hline & & $\%$ & 20.47 & 65.44 & - & 8.09 & & & & 6.94 & 58.09 & 10.69 & 13.01 & 11.27 & & \\
\hline \multirow[t]{3}{*}{5} & Instructors properly follow & $\mathrm{F}$ & 19 & 64 & $\cdot$ & 53 & & 3.36 & 1.14 & 42 & 196 & 19 & 58 & 31 & 3.46 & 1.17 \\
\hline & $\begin{array}{l}\text { up the participation of } \\
\text { students }\end{array}$ & $\%$ & 13.97 & 47.06 & - & 38.97 & & & & 12.14 & 56.65 & 5.49 & 16.76 & 8.96 & & \\
\hline & Aggregate mean & & tructors & & & & & 3.12 & 1.05 & Students & & & & & 2.77 & 1.1 \\
\hline
\end{tabular}

Item 1 of table 4 above demands respondents to indicate students' practices of challenging each other's ideas and decisions. Accordingly, the mean values 3.13 and 2.32 of the instructor and student respondents reflected 'agree' and 'disagree' respectively. However, the standard deviation 1.17 of the instructor respondents is high which indicates less concentration of instructor responses around the mean 'agree'. Therefore, it is reasonable to claim that the response of majority of the instructor respondents is approximately 'agree'. Moreover, the informants said that many of the group members could be characterized as passive listeners during group discussions. From this it could be understood that many of the students do not challenge each other's ideas and decisions.

As can be seen in the above table, the second item states students provide each other with effective and efficient help while working in a group. As can be seen from the table, the mean values 2.71 and 2.46 of the instructor and student respondents indicate 'undecided' and 'disagree'. However, as the standard deviation 1.17 is large, i.e., there is less concentration of instructor responses around 'disagreement', and more than half of the instructor respondents disagreed, then it could be said that majority of them disagreed. Based on the data collected from respondents, majority of the respondents reflected that the assistance among students in group work is not satisfactory.

Item third required respondents to indicate their observation if instructors encourage their students to actively engage in group discussion. Accordingly, the mean values 4.10 and 3.36 of the instructor and student respondents respectively ensure that as they agreed. The standard deviation 1.15 of the student respondents is greater than the standard deviation 0.76 of the instructor respondents which shows lack of consensus among students to indicate the instructors' commitment to encourage students for active participation in cooperative learning. The researcher was able to witness that instructors were encouraging their students to actively participate in group discussions. Thus, it is possible to generalize that most of the instructors encourage their students to actively participate in group discussion.

Item fourth focuses on the instructors' follow up of students' participation during group work. Accordingly, the mean values of the instructor and student respondents is 3.36 and 3.46 respectively which imply both group of the respondents agree. Thus, one can say that instructors follow up students' participation during group work.

Generally speaking, the aggregate mean values for all items were found out to be 3.12 at standard deviation of 1.05 for teachers and 2.77 at standard deviation of 1.1 for students,; and their average mean equals 2.95 at standard deviation of 1.08 which clearly showed that the practices of cooperative learning failed to created face to face instruction among the teachers and students, where the findings of the study contradicts with the views of Johnson (1998), which states that cooperative learning is a tools for creating positive interdependence among students and teachers in the classroom teaching and learning processes. 


\section{iv. Social Interaction}

Table-5: Instructors' and Students' Response on "Social Interaction" (n=136 for instructors and 346 for students)

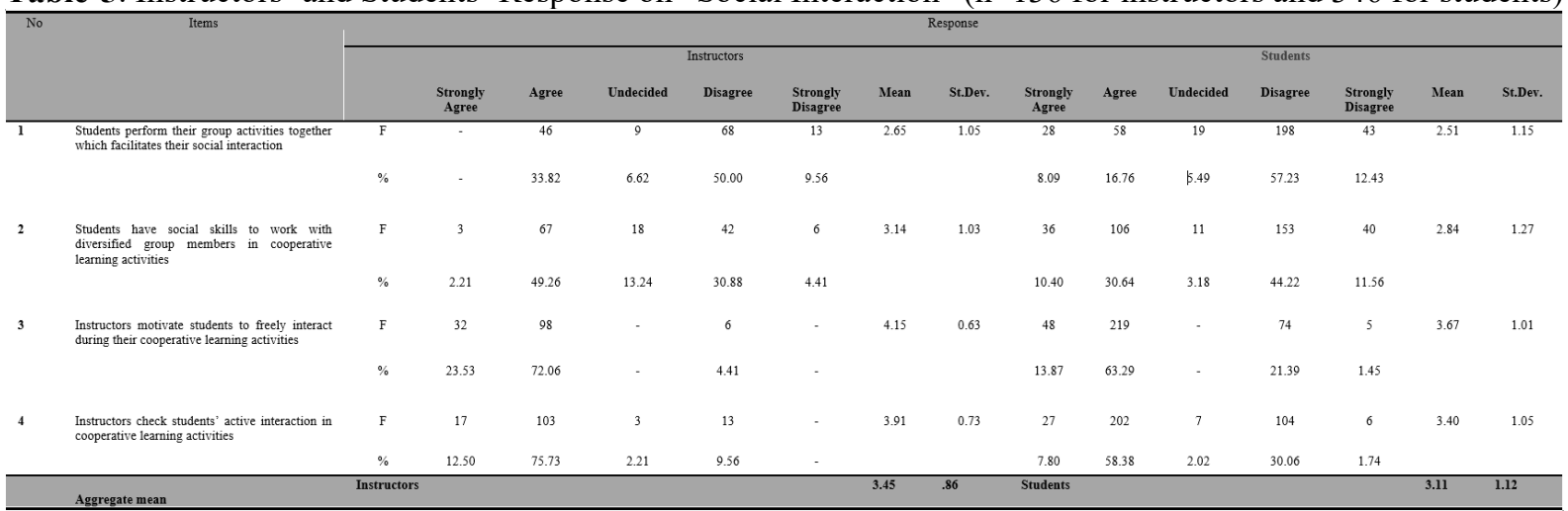

In table 5 an attempt is made to collect data that could help to determine if the cooperative learning practices in the University support social interaction among students. The first item of the above table states that students are provided with training on social skills such as how to support each other, resolve conflicts, and how to effectively communicate. For this statement, the mean values 1.89 and 2.08 of the instructor and student respondents approximately refers 'disagree'. In addition, the standard deviation 0.53 and 0.81 for the instructor and student respondents indicate a better concentration of responses around the mean values, i.e., 'disagree'. Further explanation is given by the informants which confirm that there was no training directly designed for students to improve their skills of social interaction to support the implementation of cooperative learning. They mentioned that students have the opportunity to improve their social interaction because there are courses, such as Communicative English, which are supposed to assist students in this regard. Based on the data collected, it could be concluded that students in the University were not supported with training to develop their social skills.

Item 2 of the above table requests respondents to identify whether students perform their group activities together which facilitates their social interaction. Accordingly, the mean values 2.65 and 2.51 of the instructor and student respondents respectively suggest 'disagreement'. However, the standard deviation 1.15 of the instructors is greater than 1.05 of student respondents that implies there is less concentration of student responses around 'disagreement'. In addition, the greater majority of them responded in favor of 'disagree'. Therefore, one can easily take 'disagree' as the response of majority of the student respondents consequently can be concluded that many of the students were not willing to perform their group activities together.

Item 3 of table 5 tries to assess the status of students' social skills to work with diversified group members in cooperative learning activities. Accordingly, the mean value 3.14 indicates that the instructor respondents agree with a standard deviation of 1.03 . Although the mean value 2.84 of the student respondents is nearer to 'agree' the standard deviation 1.27 is very high which could not allow to claim 'agree'. Thus, it can be confidently stated that the students did not decide whether students have social skill to work with diversified group. The researcher's personal observation indicates that despite the language barrier to communicate with the medium of instruction, majority of the students did not have problem of social skills that could greatly affect their interaction with diversified group members.

In item 4 of the above table, respondents were asked to indicate their views as to whether or not instructors check students' active interaction in cooperative learning activities. Accordingly, the 'agree' response of majority respondents is also confirmed by mean values 3.91 and 3.41 with relatively small standard deviation 0.73 and 1.05 of the instructor and student respondents. As can be seen from the responses of the respondents, many of the instructors check the active interaction of their students during cooperative learning.

Generally speaking the aggregate mean values for all items were found out to be 3.45 at standard deviation of 0.88 for teachers and 3.11 at standard deviation of 1.12 for students, which clearly showed that the practices of cooperative learning created social interactions among teachers and students, where the findings of the study coincides with the views of Wang (2009), which states that cooperative learning is a instrument for creating social interactions among students and teachers in the classroom teaching and learning processes. 


\section{Benefits of Cooperative Learning}

Table-6: Instructors' and Students' Response on "Benefits of Cooperative Learning” ( $\mathrm{n}=136$ for instructors and 346 for students)

\begin{tabular}{|c|c|c|c|c|c|c|c|c|c|c|c|c|c|c|c|c|}
\hline \multirow[t]{3}{*}{ No } & \multirow[t]{3}{*}{ Items } & & \multicolumn{14}{|c|}{ Response } \\
\hline & & & \multicolumn{6}{|c|}{$\begin{array}{l}\text { Instructors } \\
\end{array}$} & & \multicolumn{7}{|c|}{$\begin{array}{c}\text { Students } \\
\text { s. }\end{array}$} \\
\hline & & & $\begin{array}{c}\text { Strongly } \\
\text { Agree }\end{array}$ & Agree & Undecided & Disagree & $\begin{array}{l}\text { Strongly } \\
\text { Disagree }\end{array}$ & Mean & St.Der. & $\begin{array}{c}\text { Strongly } \\
\text { Agree }\end{array}$ & Agree & Undecided & Disagree & $\begin{array}{l}\text { Strongly } \\
\text { Disagree }\end{array}$ & Mean & St.Dev \\
\hline 1 & Students havc acquired better knowldedge. & $\frac{\mathrm{F}}{\%}$ & $\therefore$ & $\begin{array}{c}67 \\
4927\end{array}$ & $\begin{array}{c}19 \\
13.98\end{array}$ & $\begin{array}{c}50 \\
36.75\end{array}$ & : & 3.13 & 0.92 & $\begin{array}{c}41 \\
11.85\end{array}$ & $\begin{array}{l}1999 \\
5752\end{array}$ & $\begin{array}{l}32 \\
9.25\end{array}$ & $\begin{array}{c}68 \\
10.65\end{array}$ & $\begin{array}{c}6 \\
1.73\end{array}$ & 3.58 & 0.99 \\
\hline \multirow[t]{2}{*}{2} & \multirow{2}{*}{$\begin{array}{l}\text { Students have developed critical thinking and } \\
\text { reasoning skills }\end{array}$} & $\mathrm{F}$ & & 49 & 13 & 74 & - & 2.82 & 0.04 & 13 & 186 & 23 & 101 & 23 & \multirow[t]{2}{*}{3.10} & \multirow[t]{2}{*}{1.10} \\
\hline & & $\%$ & & 36.03 & 9.56 & 54.41 & & & & 3.76 & 53.75 & 6.65 & 29.19 & 6.65 & & \\
\hline \multirow[t]{3}{*}{3} & \multirow{3}{*}{$\begin{array}{l}\text { Strdents have improved their academic } \\
\text { achierement } \\
\text { Students have gained better opportunity to learn } \\
\text { easier }\end{array}$} & $\mathrm{F}$ & 7 & 69 & 4 & 54 & 2 & 3.18 & 1.07 & 51 & 213 & 5 & 63 & 14 & 3.05 & \multirow[t]{2}{*}{1.07} \\
\hline & & $\mathrm{F}$ & $\underset{5}{\frac{5.14}{5}}$ & ${ }_{74}^{50 / 7}$ & 2.94 & $\begin{array}{l}30.71 \\
39\end{array}$ & ${ }_{11}^{1.47}$ & 317 & 113 & $\begin{array}{l}14.73 \\
20\end{array}$ & $\begin{array}{l}61.56 \\
188\end{array}$ & $\begin{array}{l}1.45 \\
31\end{array}$ & 18.21 & $\begin{array}{l}4.05 \\
10\end{array}$ & & \\
\hline & & $\%$ & 3.68 & 54.41 & 5.14 & 28.68 & 8.09 & 2.11 & $1.1 \mathrm{~T}$ & 7.51 & 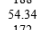 & 8.96 & 26.30 & 2.89 & \multirow[b]{2}{*}{3.11} & \multirow{2}{*}{$\begin{array}{c}1.04 \\
1.05\end{array}$} \\
\hline \multirow[t]{2}{*}{5} & \multirow[t]{2}{*}{ Students have developed self-confidence } & $\mathrm{F}$ & & ${ }_{4632}^{63}$ & 11 & ${ }^{60}$ & $\stackrel{2}{147}$ & 2.99 & 0.99 & 12 & 172 & 8 & ${ }_{436}^{151}$ & 38 & & \\
\hline & & $\%$ & : & $\begin{array}{l}46.32 \\
66\end{array}$ & $\begin{array}{l}8.09 \\
18\end{array}$ & $\begin{array}{l}44.12 \\
52\end{array}$ & 1.47 & 3.10 & 0.93 & $\begin{array}{l}3.47 \\
24\end{array}$ & $\begin{array}{l}49.71 \\
164\end{array}$ & $\begin{array}{l}2.31 \\
15\end{array}$ & 年. 304 & $\frac{0.87}{4}$ & 3.19 & 1.08 \\
\hline 6 & \multirow{3}{*}{$\begin{array}{l}\text { Students have improved their interpersonal skills } \\
\text { Students have developed decision making and } \\
\text { conflict management skills }\end{array}$} & $\%$ & \multirow{2}{*}{$\begin{array}{c}3 \\
2.21\end{array}$} & $\begin{array}{l}48.52 \\
61\end{array}$ & $\begin{array}{l}13.24 \\
14\end{array}$ & $\begin{array}{c}38.24 \\
58\end{array}$ & $\therefore$ & 3.07 & 0.98 & ${ }_{13}^{6.94}$ & $\begin{array}{l}47.40 \\
151\end{array}$ & $\begin{array}{l}4.34 \\
32\end{array}$ & $\begin{array}{l}40.17 \\
1.24\end{array}$ & $\begin{array}{l}1.15 \\
26\end{array}$ & \multirow{2}{*}{3.00} & \multirow{2}{*}{1.12} \\
\hline \multirow[b]{2}{*}{8} & & $\%$ & & 44.85 & 10.29 & 42.65 & - & 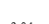 & & 3.76 & 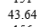 & 9.25 & 35.84 & 7.51 & & \\
\hline & & $\mathrm{F}$ & - & $\begin{array}{c}58 \\
42.64\end{array}$ & $\begin{array}{c}26 \\
19.12\end{array}$ & $\begin{array}{c}52 \\
3884\end{array}$ & - & 3.04 & 0.90 & ${ }_{16}^{16}$ & $\begin{array}{c}156 \\
4500\end{array}$ & 21 & ${ }_{442}^{142}$ & 11 & 3.07 & 1.08 \\
\hline \multirow[t]{2}{*}{9} & \multirow{2}{*}{$\begin{array}{l}\text { Students have developed ability to work with } \\
\text { diversified group members }\end{array}$} & $\mathrm{F}$ & & 59 & 13 & $\begin{array}{c}0.24 \\
64\end{array}$ & & 2.96 & 0.95 & 33 & 149 & 19 & $\begin{array}{l}14.04 \\
143\end{array}$ & 2 & \multirow{2}{*}{3.20} & \multirow{2}{*}{1.10} \\
\hline & & $\%$ & & 43.38 & 9.56 & 47.06 & & & & 0.54 & 43.06 & 5.49 & 41.33 & 0.58 & & \\
\hline 10 & $\begin{array}{l}\text { Students have understood the importance of } \\
\text { worting togetern }\end{array}$ & $\mathrm{F}$ & 4 & 73 & 9 & 43 & 7 & 3.18 & 1.07 & 12 & 201 & 16 & 103 & 14 & 3.27 & 1.05 \\
\hline & & & 2.04 & 53.68 & 6.62 & 31.62 & 5.14 & & & 3.47 & 5800 & 4.62 & 20.77 & 4.05 & & \\
\hline
\end{tabular}

As can be shown in item 1 of table 6 , respondents were requested to indicate their opinion for the 10 items related with expected benefits of cooperative learning. In item one of this table, $41(11.85 \%)$ of the student respondents strongly agreed; and 67 (49.27\%) of the instructor and $199(57.52 \%)$ of the student respondents agreed that students have acquired better knowledge as a result of implementation of cooperative learning. 19 (1398\%) of the instructor and $32(9.25 \%)$ of the student respondents are unable to decide on the significance of cooperative learning in helping students to acquire better knowledge. In contrary, $50(36.75 \%)$ of the instructor and $68(19.65 \%)$ of the student respondents disagreed while $6(1.73 \%)$ of the student respondents strongly disagreed because they do not believe that students gained better knowledge. It seems possible to conclude that cooperative learning helped students somehow to acquire better knowledge.

According to the second item of the above table, $13(3.76 \%)$ of the student respondents strongly agreed; and $49(36.03 \%)$ of the instructor and $186(53.75 \%)$ of the student respondents agreed to express their view that the implementation of cooperative learning helped students to develop their critical thinking and reasoning skills. A small number of respondents $(13,9.56 \%$ of the instructors and $23,6,65 \%$ of the students) undecided for the item stated as "students have developed critical thinking and reasoning skills." When $74(54.41 \%)$ of the instructor and $101(29.19 \%)$ of the student respondents disagreed, the remaining $23(6.65 \%)$ of the student respondents strongly disagreed which implies that cooperative learning did not contribute for students to develop their critical thinking and reasoning skills. It is possible to observe that respondents are inclined to recognize the role cooperative learning played to improve students' critical thinking and reasoning skills.

In item 3 of the above table $6,(5.14 \%)$ of the instructor and $51(14.73 \%)$ of the student respondents strongly agreed while $69(50.74 \%)$ of the instructor and $213(61.56 \%)$ of the student respondents agreed consequently they admitted that students have improved their academic achievement. Insignificant number of the respondents (4, $2.94 \%$ of the instructors and $5,1.45 \%$ of the students) undecided. In contrary, $54(39.71 \%)$ of the instructor and $63(18.21 \%)$ of the student respondents disagreed; and $2(1.47 \%)$ of the instructor and $14(4.05 \%)$ of the student respondents strongly disagreed that students did not improve their academic achievement in the University. On the basis of the data presented above, majority of the respondents admitted the improvement of students' academic achievement due to the implementation of cooperative learning in the University.

As can be seen in item 4 of table6, $5(3.68 \%)$ of the instructor and $26(7.51 \%)$ of the student respondents strongly agreed whereas $74(54.41 \%)$ of the instructor and $188(54.34 \%)$ of the student respondents agreed who admitted the opportunity students gained to learn easily. $7(5.14 \%)$ of the instructor and $31(8.96 \%)$ of the student respondents failed to decide about such an opportunity. On the other hand, $39(28.68 \%)$ of the instructor and 91 $(26.30 \%)$ of the student respondents disagreed while $11(8.09 \%)$ of the instructor and $10(2.99 \%)$ of the student respondents strongly disagreed that the implementation of cooperative learning did not help students to learn easier. From this it can be said that majority of the respondents confirmed that students gained an opportunity to learn easier due to the implementation of cooperative learning.

Item 5 of the above table asked the respondents to indicate their believe about the benefit of cooperative learning in developing students' self-confidence. Thus, $12(3.47 \%)$ of the student respondents strongly agreed; and $63(46.32 \%)$ of the instructor and $172(49.71 \%)$ of the student respondents agreed who replied that students have developed self-confidence. Those respondents who failed to decide about the improvement of students' selfconfidence are $11(8.09 \%)$ of the instructors and $8(2.31 \%)$ of students. In contrary to this, $60(44.12 \%)$ of the instructor and $151(43.64 \%)$ of the student respondents disagreed while $2(1.47 \%)$ of the instructor and $3(0.87 \%)$ of the student respondents strongly disagreed whereby they asserted that the implementation of cooperative learning did not help students to develop their self-confidence. Based on this data, nearly majority of the respondents reflected their agreement consequently it seems possible to conclude that there is some improvement in developing students' self-confidence. 
From item 6 of table 6 , it can be seen that 24 (6.94\%) of the student respondents strongly agreed whereas 66 $(48.52 \%)$ of the instructor and $164(47.40 \%)$ of the student respondent agreed that students have improved their communication skills. Others, 18 (13.24\%) of the instructor and $15(4.34 \%)$ of the student respondents did not decide about the improvement of students' communication skills. The remaining 52 (38.24\%) of the instructor and $139(40.17 \%)$ of the student respondents disagreed; and $4(1.15 \%)$ of the student respondents strongly disagreed. One can observe that larger number of respondents inclined to admit that students somehow developed their communication skills.

In item 7 of the above table, $3(2.215)$ of the instructor and $13(3.76 \%)$ of the student respondents strongly agreed; and $61(44.85 \%)$ of the instructor and $151(43.64 \%)$ of the student respondents agreed that students have developed their interpersonal skills. $14(10.29 \%)$ of the instructor and $32(9.25 \%)$ of the student respondents undecided. On the other hand, 58 (42.68\%) of the instructor and $124(35.84 \%)$ of the student respondents disagreed while $26(7.51 \%)$ of the student respondents strongly disagreed consequently they reported their belief that the implementation of cooperative learning in the University did not help students to develop their interpersonal skills. As can be seen from the discussion of the data, considerable number of the respondents claimed that students were able to improve their interpersonal skills due to the implementation of cooperative learning in Wollo University.

Item 8 of table 6 requested respondents to identify if cooperative learning helped students to develop their decision making and conflict management skills. Accordingly, $16(4.62 \%)$ of the student respondents strongly agreed whereas $58(42.64 \%)$ of the instructor and $156(45.09 \%)$ of the student respondents agreed that cooperative learning contributed for students to develop their decision making and conflict management skills. A small number of respondents, $25(19.12 \%)$ of the instructors and $21(6.07 \%)$ of the students are unable to decide to agree or disagree about the statement of the item. In contrary, $52(38.24 \%)$ of the instructor and $142(41.04 \%)$ of the student respondents disagreed while the remaining $11(3.18 \%)$ of the student respondents strongly disagreed through which they reported that the implementation of cooperative learning did not help students to develop decision making and conflict management skills. From this data, it could be understood that students showed some improvements in their decision making and conflict management skills.

In item 9 of the above table, $33(9.54 \%)$ of the student respondents strongly agreed; and $59(43.38 \%)$ of the instructor and $149(43.06 \%)$ of the student respondents agreed that students have developed ability to work with diversified group members. Those respondents who did not decide about the students' improvement in their ability to work with diversified group members were $13(9.54 \%)$ of the instructor and $19(5.49 \%)$ of the student respondents. In contrast to this, $64(47.06 \%)$ of the instructor and $143(41.33 \%)$ of the student respondents disagreed whereas the remaining $2(0.58 \%)$ of the student respondents strongly disagreed consequently they made clear that cooperative learning did not help students to develop their ability to work with diversified group members. It is possible to understand that students somehow improved their ability to work with diversified group members.

Finally, in item 10 of the above table, $4(2.94 \%)$ of the instructor and $12(3.47 \%)$ of the instructor respondents strongly agreed; and $73(53.68 \%)$ of the instructor and $201(58.09 \%)$ of the student respondents agreed that students have understood the importance of working together. A small number of the respondents, $9(6.62 \%)$ of the instructor and $16(4.62 \%)$ of the student respondents failed to determine if students were able to understand the importance of working together. In contrary, $43(31.62 \%)$ of the instructor and $102(29.77 \%)$ of the student respondents disagreed whereas $7(5.14 \%)$ of the instructor and $14(4.05 \%)$ of the student respondents strongly disagreed which means they believed that students did not understood the importance of cooperative learning. From this, it is possible to understand that there is improvement among students in their understanding about cooperative learning.

The above table has attempted to assess the benefits gained due to the implementation of cooperative learning in Wollo University. The mean values of both instructor and student respondents for most of the items is greater than 3, which suggests 'agree'. The standard deviation of instructors' responses is less than 1 for most of the items which could lead to rely the mean value. However, the standard deviation of students' responses for most of the items is a little bit greater than 1, which may make difficult to accept the mean values in full confidence. In support of the mean values, informants claimed that students gained benefits from cooperative learning. But informants made clear that compared with its expected benefits, the stated benefit students gained from cooperative learning was not satisfactory. From this, it could be understood that to some extent students were benefited from the implementation of cooperative learning in the University. 


\section{Challenges of Cooperative Learning}

Table-7: Instructors' and Students' Response on "Challenges of Cooperative Learning” ( $\mathrm{n}=136$ for instructors and 346 for students)

\begin{tabular}{|c|c|c|c|c|c|c|c|c|c|c|c|c|c|c|c|c|}
\hline \multirow[t]{3}{*}{ No } & \multirow[t]{3}{*}{ Items } & & \multicolumn{14}{|c|}{ Response } \\
\hline & & & \multicolumn{6}{|c|}{ Instructors } & & \multicolumn{7}{|c|}{ 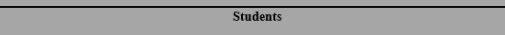 } \\
\hline & & & $\begin{array}{c}\text { Strougly } \\
\text { Agree }\end{array}$ & Agree & Undecided & Disagree & $\begin{array}{l}\text { Srrongly } \\
\text { Disagree }\end{array}$ & Mean & st.Dev. & $\begin{array}{c}\text { Srrongly } \\
\text { Agree }\end{array}$ & Agree & Undecided & Disagree & $\begin{array}{l}\text { Surongly } \\
\text { Disagree }\end{array}$ & Mean & St.Dev. \\
\hline 1 & Lack of awareness and experiences about cooperative & $\mathrm{F}$ & 52 & 78 & - & 6 & - & 4.29 & 0.69 & 31 & 194 & 21 & 92 & 8 & 3.43 & 1.05 \\
\hline 2 & $\begin{array}{l}\text { learning } \\
\text { Poor coordination of group member contributions }\end{array}$ & $\begin{array}{l}\% \\
\mathrm{~F} \\
\%\end{array}$ & $\begin{array}{c}38.24 \\
9 \\
6.62\end{array}$ & $\begin{array}{c}57.35 \\
81 \\
59.56\end{array}$ & $\begin{array}{l}13 \\
956\end{array}$ & $\begin{array}{c}4.41 \\
29 \\
21.32\end{array}$ & $\begin{array}{c}\overline{4} \\
294\end{array}$ & 3.46 & 1.00 & $\begin{array}{c}8.96 \\
19 \\
549\end{array}$ & $\begin{array}{c}56.07 \\
198 \\
5723\end{array}$ & $\begin{array}{c}6.07 \\
3 \\
0.86\end{array}$ & $\begin{array}{c}26.59 \\
117 \\
33.82\end{array}$ & $\begin{array}{c}231 \\
9 \\
260\end{array}$ & 3.29 & 1.07 \\
\hline 3 & Lack of students' motivation to work in group & $\mathrm{F}$ & 38 & 91 & - & 7 & - & 4.18 & 0.68 & 20 & 200 & - & 123 & 3 & 3.32 & 1.05 \\
\hline 4 & Uncqual sharing of work among group members & $\begin{array}{l}\% \\
\mathrm{~F} \\
\%\end{array}$ & $\begin{array}{c}27.94 \\
7.15\end{array}$ & $\begin{array}{c}66.91 \\
74 \\
54.41\end{array}$ & $\vdots$ & $\begin{array}{c}5.15 \\
55 \\
40.44\end{array}$ & $\vdots$ & 3.24 & 1.05 & $\begin{array}{c}5.78 \\
49 \\
14.16\end{array}$ & $\begin{array}{c}57.23 \\
178 \\
51.45\end{array}$ & $\begin{array}{c}4 \\
1.16\end{array}$ & $\begin{array}{c}35.55 \\
77 \\
22.26\end{array}$ & $\begin{array}{c}0.87 \\
38 \\
10.98\end{array}$ & 3.36 & 1.27 \\
\hline 5 & Insufficient support and follow-up from instructors & F & $\begin{array}{c}15 \\
11.03\end{array}$ & $\begin{array}{c}42 \\
30.88\end{array}$ & 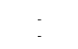 & $\begin{array}{c}71 \\
52.21\end{array}$ & $\begin{array}{c}8 \\
5.88\end{array}$ & 2.89 & 1.23 & $\begin{array}{c}58 \\
56.76\end{array}$ & $\begin{array}{l}239 \\
69.08\end{array}$ & $\begin{array}{c}9 \\
2.60\end{array}$ & $\begin{array}{l}27 \\
7.80\end{array}$ & $\begin{array}{c}13 \\
3.76\end{array}$ & 3.87 & 0.91 \\
\hline \multirow[b]{2}{*}{7} & Domination of some group members (highter achievers) & F & $\begin{array}{c}34 \\
25.00\end{array}$ & $\begin{array}{r}101 \\
74.26\end{array}$ & : & $\begin{array}{c}1 \\
0.74\end{array}$ & - & 4.23 & 0.52 & $\begin{array}{c}62 \\
17.92\end{array}$ & $\begin{array}{l}262 \\
75.72\end{array}$ & $\begin{array}{c}2 \\
0.58\end{array}$ & $\begin{array}{l}16 \\
4.62\end{array}$ & $\stackrel{4}{1.16}$ & 4.05 & 0.69 \\
\hline & Unfair assessment result for group work & F & ${ }_{101}^{23}$ & $\begin{array}{c}72 \\
5204\end{array}$ & $=$ & 38 & 3 & 3.54 & 1.13 & 39 & 198 & 5 & 97 & 7 & 3.48 & 1.08 \\
\hline 8 & Too large class size & $\%$ & & $\begin{array}{c}52.94 \\
14\end{array}$ & & $\begin{array}{l}27.94 \\
122\end{array}$ & 2.21 & 2.21 & 0.61 & ${ }_{8}^{11.27}$ & $\begin{array}{l}5123 \\
16\end{array}$ & & $\begin{array}{l}28.03 \\
298\end{array}$ & $\begin{array}{l}2.02 \\
24 \\
24\end{array}$ & 2.09 & 0.68 \\
\hline 9 & Relating cooperative learning with politics & ${ }_{\mathrm{F}}^{\frac{\%}{6}}$ & & $\begin{array}{c}10.29 \\
86\end{array}$ & $=$ & $\begin{array}{l}80.71 \\
19\end{array}$ & : & 3.95 & 0.89 & ${ }_{63}^{231}$ & $\begin{array}{l}4.62 \\
228\end{array}$ & 46 & $\begin{array}{c}86.13 \\
9\end{array}$ & 6.94 & 4.00 & 0.65 \\
\hline 10 & Students' por interersonal and compunication skill & $\%$ & $\begin{array}{c}22.79 \\
53\end{array}$ & ${ }_{78}^{63.24}$ & - & $\frac{13.97}{5}$ & - & 432 & & ${ }_{18.21}$ & 65.90 & 13.29 & 2.60 & 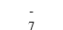 & 232 & 083 \\
\hline & Students' poor interpersonal and communication skill & F & $\begin{array}{c}53 \\
38.97\end{array}$ & 57.35 & $\therefore$ & $\begin{array}{c}5 \\
3.68\end{array}$ & 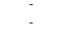 & 4.32 & & $\begin{array}{l}12 \\
3.47\end{array}$ & $\begin{array}{c}38 \\
10.98\end{array}$ & 2.02 & $\begin{array}{l}282 \\
81.50\end{array}$ & 2.03 & 2.32 & 0.83 \\
\hline
\end{tabular}

In this part, discussion and presentation of data about challenges of cooperative learning is conducted which is presented as follows. As it is shown in the above table, except for items 7 and 11, the instructor respondents rated 'agree' with the mean values greater than 3.2. The standard deviation of instructor respondents for most of the items is less than one which implies great concentration of responses around 'agree'. With regard to item 7, despite majority of the instructors rated 'disagree' the mean value 2.89 is within the range of 'undecided' with a higher standard value of 1.23. Thus, the rate 'undecided' which is indicated by the mean value of instructor respondents for this item seems to have been acceptable consequently were not certain to support or reject the statement of the item stated as "Insufficient support and follow-up from instructors". With regard to item 11, which demanded respondents to rate the prevalence of too large class size in the University, the instructor and student respondents rated disagree with the mean values of 2.21 and 2.09 respectively. The standard deviation 0.61 and 0.68 is low which supports to fully accept the rated mean value of 'disagree'.

Similarly, the mean value $\geq 3.29$ of the student respondents for most of the items about challenges of cooperative learning suggests the rate 'agree'. The standard deviation is also less than one which is in favor of better concentration of responses rated 'agree'. The exceptions are items 9, 11 and 14 whereby the mean value 2.44, 2.09 and 2.32 respectively indicate 'disagree'. For item 9, which is about "Dependence of lower achiever students on higher achievers," students did not perhaps to openly admit the problem. The presence of the problem is clearly indicated by instructor respondents by rating 'agree' in this item, as well as by some instructor and student respondents by writing their view in the space provided for the open-ended questions. Concerning item 14 (students' poor interpersonal and communication skills), students did not admit. As explained earlier, the crucial problem in this regard seems not poor interpersonal and communication skills but language barrier or failure to effectively communicate with the medium of instruction, i.e., English. In addition to the interpretation of data using mean and standard deviation value, an attempt is made to analyze the data in the above table using frequency and percentage values as follows.

As can be seen in the first item of table 7, $52(38.24 \%)$ of the instructor and $31(8.96 \%)$ of the student respondents strongly agreed that lack of awareness about cooperative learning is a challenge for the implementation of cooperative learning. 78 (57.35\%) of the instructor and $194(56.07 \%)$ of the student respondents agreed that lack of awareness is a challenge in the University. None of the instructor and $21(6.06 \%)$ of the student respondents undecided. Others, $6(4.41 \%)$ of the instructor and $92(26.59 \%)$ of the student respondents disagreed who rejected lack of awareness as a challenge for the implementation of cooperative learning. The remaining 8 $(2.31 \%)$ of the student respondents strongly disagreed. From the discussion of the data, it is clear that lack of awareness about cooperative learning is one of the challenges for its implementation in Wollo University. Even some of the informants argued that cooperative learning has a negative impact on the academic status of students because as to them this method made many of the students to be dependent on the high achiever students. This attitude of instructors towards cooperative learning might be developed due to poor their poor implementation of this method.

Item 2 of the above table presents data collected from respondents on "poor coordination of group member contributions." From the total respondents, 9 (6.62\%) of the instructors and 19 (5.49\%) of the student respondents strongly agreed whereas $81(59.56 \%)$ of the instructor and $198(57.23 \%)$ of the student respondents agreed that poor coordination of group member contributions could be considered as a challenge for the proper implementation of cooperative learning in Wolloo University. Some of the respondents $(13,9.56 \%$ of the instructors and 3, $0.86 \%$ of the student respondents) undecided to clarify their agreement or disagreement concerning poor coordination of group member contributions as a challenge. $29(21.32 \%)$ of the instructor and $117(33.82 \%)$ of the student respondents disagreed. Besides, $4(2.94 \%)$ of the instructor and $9(2.60 \%)$ of the student respondents strongly 
disagreed through which they reported that poor coordination of group member contributions is not a challenge for the implementation of cooperative learning in the University. Finally, the data collected from respondents for this item leads to a conclusion that majority of the respondents admitted the existence of poor coordination of group member contribution. The observation of the researcher confirmed that usually poor coordination of group member contribution is prevailed.

As can be seen from item 3 of the above table, $38(27.94 \%)$ of the instructor and $20(5.78 \%)$ of the student respondents strongly agreed; and $91(66.91 \%)$ of the instructor and $200(57.80 \%)$ of the student respondents agreed confirming that lack of students' motivation to work in group can be taken as a challenge for the implementation of cooperative learning in the University. Those respondents who disagreed about the challenge that could be prevailed due to lack of students' motivation to work in group are $7(5.15 \%)$ instructors and $123(35.55 \%)$ students. The remaining $3(0.87 \%)$ of the student respondents claimed they strongly disagreed that lack of students' motivation to work in group could not be considered as a challenge for the proper implementation of cooperative learning in the University. Here majority of the respondents revealed their agreement for the idea stated in this item. The interview evidence indicated that many of the group members were not active participants in their cooperative learning activities.

Item 4 of table 7 demanded respondents to reflect their view whether unequal sharing of work among group members is a challenge for the implementation of cooperative learning or not. In view of that, $7(5.15 \%)$ of the instructor and $49(14.16 \%)$ of the student respondents strongly agreed. As well, $74(54.41 \%)$ of the instructor and $178(51.45 \%)$ of the student respondents agreed that unequal sharing of work among group members is a challenge for the implementation of cooperative learning. Only $4(1.16 \%)$ of the student respondents undecided thus they failed to reflect their agreement or disagreement. On the other hand, $55(40.44 \%)$ of the instructor and $77(22.26 \%)$ of the student respondents disagreed while only $38(10.98 \%)$ of the student respondents strongly disagreed which means they do not accept unequal sharing of work among group members as a challenge for the implementation of cooperative learning. As majority of the respondents reflected their agreement, it can be said that unequal sharing of work among group members is a serious challenge for the implementation of cooperative learning.

In item 5 of table $7,15(11.03 \%)$ of the instructor and $58(16.76 \%)$ of the student respondents strongly agreed; and $42(30.88 \%)$ of the instructor and $239(69.08 \%)$ of the student respondents agreed that insufficient support and follow-up from instructors is taken as a challenge for the implementation of cooperative learning. Only student respondents $(9,2.60 \%)$ did not decide to express their agreement or disagreement whether the support and followup from instructors is sufficient or not. $71(52.21 \%)$ of the instructor and $27(7.80 \%)$ of the student respondents disagreed whereas $8(5.88 \%)$ of the instructor and $13(3.76 \%)$ of the student respondents strongly disagreed which is to mean the support and follow-up from the instructors is sufficient. As can be seen, though majority of the student respondents claimed that the support and follow-up from the instructors is insufficient, majority of the instructor respondents reflected their disagreement who believed that the support and follow-up from the instructors is sufficient. Despite majority of the instructors believed that their support and follow up of students was sufficient, the mean value 2.89 indicates the rate 'undecided'. In addition, informants explained that the instructors' support and follow up to enable students actively engaged in cooperative learning was not satisfactory. Thus, it could be said that the instructors' support and follow up of their students was not sufficient.

As it is evident in item 6 of the above table, $34(25.00 \%)$ of the instructor and $62(17.92 \%)$ of the student respondents strongly agreed while $101(74.26 \%)$ of the instructor and $262(75.72 \%)$ of the student respondents agreed that domination of some of the group members or higher achievers is a challenge for the effective implementation of cooperative learning in the University. None of the instructor and $2(0.58 \%)$ of the student respondents undecided. In contrast, $1(0.74 \%)$ of the instructor and $16(4.62 \%)$ of the student respondents disagreed; and only $4(1.16 \%)$ of the student respondents strongly disagreed in which they reported that domination of some of the group members or higher achievers is not a problem in implementing cooperative learning. From this it could be said that the great majority of the respondents considered domination of some of the group members or higher achievers is a challenge in the University.

Item 7 of table 7 asked respondents to indicate their view whether unfair assessment result for group work is a challenge for the implementation of cooperative learning or not. For this item, $23(16.91 \%)$ of the instructor and $39(11.27 \%)$ of the student respondents strongly agreed whereas $72(52.94 \%)$ of the instructor and $198(57.23 \%)$ of the student respondents agreed recognizing unfair assessment result for group work as a challenge for the implementation of cooperative learning in the University. $5(1.45 \%)$ student respondents only undecided. The remaining 38 (27.94\%) of the instructor and 97 (28.03\%) of the student respondents disagreed; and $3(2.21 \%)$ of the instructor and $7(2.02 \%)$ of the student respondents strongly disagreed consequently they made clear that assessment result while practicing cooperative learning is fair. From this, it can be understood majority of the respondents confirmed that unfair assessment result for group work is a challenge in the University. Informants added that there were occasions where by instructors give equal mark for group assignments of all group in a class. Besides, since students and even some of the instructors assume assignments as a "subsidy" inflated mark is given for assignments. 
In item 8 of the above table, $8(2.31 \%)$ of the student respondents strongly agreed while $14(10.29 \%)$ of the instructor and $16(4.62 \%)$ of the student respondents agreed that too large class size is a challenge for the implementation of cooperative learning. The greater majority of the respondents $(122,89.71 \%$ of the instructors and $298,86.13 \%$ of the students) disagreed whereas $24(6.94 \%)$ of the student respondents strongly disagreed thus they reported that class size is not a problem in implementing cooperative learning in Wollo University. As a result, the data indicates that class size is not a critical problem in the University.

Item 9 of table 7 demanded respondents to identify if students and instructor in the University relate cooperative learning with politics. From the total respondents, $31(22.79 \%)$ of the instructor and $63(18.21 \%)$ of the student respondent strongly agreed; and $86(63.24 \%)$ of the instructor and $228(65.90 \%)$ of the student respondents agreed that relating cooperative learning with politics affect the proper implementation of cooperative learning. Those respondents who did not decide are $46(13.29 \%)$ students. $19(13.97 \%)$ of the instructor and 9 $(2.60 \%)$ of the student respondents disagreed that relating cooperative learning with politics is not a challenge for the implementation of cooperative learning. From the data presented, one can observe the great majority of respondents confirmed that relating cooperative learning with politics was s a challenge in practicing cooperative learning.

In item 10 of the above table, $53(38.97 \%)$ of the instructor and $12(3.47 \%)$ of the student respondents strongly agreed whereas $78(57.35 \%)$ of the instructor and $38(10.98 \%)$ of the student respondents agreed that students' poor interpersonal and communication skill could be considered as a challenge for implementing cooperative learning. Only $7(2.02 \%)$ of the student respondents are uncertain to decide that students' poor interpersonal and communication skill is a challenge. $5(3.68 \%)$ of the instructor and $282(81.50 \%)$ of the student respondents disagreed while $7(2.03 \%)$ of the student respondents strongly disagreed by which they reflected that do not take students' poor interpersonal and communication skill as a challenge. Although majority of the instructor respondents considered students' poor interpersonal and communication skill as a challenge during implementing cooperative learning, majority of the student respondents do not agree. The researcher was able to observe that students' failure to effectively communicate by the instructional media was a challenge for the students in group discussions.

Table 8: Significance value computed from the mean values of instructor and student respondents on different indicators of implementation of Cooperative learning

\begin{tabular}{llrrrrr}
\hline \multirow{2}{*}{ No Item } & & \multicolumn{2}{c}{ Mean } & t & df & Sig. \\
\cline { 3 - 5 } & & Instructors & Students & & & \\
\hline $\mathbf{1}$ & Positive interdependence & 2.79 & 3.13 & -1.182 & 16 & .254 \\
$\mathbf{2}$ & Individual accountability & 2.67 & 2.68 & -.47 & 10 & .963 \\
$\mathbf{3}$ & Face to face interaction & 3.17 & 2.77 & 1.051 & 8 & .324 \\
$\mathbf{4}$ & Social interaction & 3.10 & 2.82 & .664 & 10 & .522 \\
$\mathbf{5}$ & Challenges of cooperative learning & 3.72 & 3.35 & 1.642 & 28 & .112 \\
$\mathbf{6}$ & Benefits of cooperative learning & 3.07 & 3.26 & -3.078 & 22 & .006 \\
\hline
\end{tabular}

Using an independent sample t-test, an attempt is made to measure the mean difference between instructor and student respondents on different indicators of implementation of cooperative learning and to determine if there is statistically significant mean difference between the two group of respondents. Accordingly, with the exception of item 7 , the significant value of other items is greater than 0.05 level. This implies that there is no statistically significant mean difference between instructor and student respondents on Positive interdependence, Individual accountability, Face to face interaction, Social interaction, Group processing and Challenges of cooperative learning. However, a clear mean value difference is observed for the last item, i.e., benefits of cooperative learning. The last item is about benefits students gained due to the implementation of cooperative learning in the University. As can be seen from the t-test, instructor and student respondents did not have common consensus about the benefits students acquired from cooperative learning.

\section{Conclusions and Recommendations \\ Conclusions}

On the bases of the results and discussion drawn from the summarized data, the writers forwarded the following conclusions.

$>$ In cooperative learning, students are expected to be positively interdependent. In this regard the study found out that students of the university believed supporting each other in their respective group have a contribution to meet their academic goals. In contrary to this, it is possible to say that many of the group members restricted themselves during their group discussion from openly disclose the points of the group discussion which are not clear for them. It is possible to conclude that majority students of the university failed to freely demand assistance from their group members. Although groups were organized putting sex and academic status composition into consideration, it is difficult to conclude that they fulfil the status of cohesive group. It also becomes evident that students in a group did not equally cooperate in learning 
activities and it is identified that there were students who fail to take responsibility for success or failure of each group member. In relation with this, evidences confirmed that students assumed tutoring other group members consumes their time thus they are not willing to provide such assistance. Thus, it can be concluded that there is a great gap among students to tutor each other until each member of their group understands the material.

$>$ The study found out that most of the roles in cooperative learning were imposed on some of the group members, particularly the group leader, which is a great burden for them. Besides, only some of the group members were ready to help their teammates. One of the strengths of the instructors in supporting the implementation of cooperative learning was that many of them frequently checked the contribution of each group member specifically during group discussions. This somehow could assist the students to be responsible for their assigned group tasks and actively involved in group learning activities.

$>$ As to the issues related with face to face interaction of the students during cooperative learning, the analyzed data revealed that there is greater gap among students in freely sharing their ideas, views and feelings. It was found out that many of the students did not challenge each other's ideas and decisions. It is also confirmed that the assistance among students in group work was not satisfactory. Although the reaction from students was not satisfactory, most of the instructors seemed to have encouraged their students to actively participate in group discussion.

- Concerning the benefits students gained from cooperative learning, it could be concluded that to some extent they were benefited as it helped them to improve their critical thinking and reasoning skills, academic achievement, self-confidence, communication skills as well as team spirit and consensus building. In general, the implementation of cooperative learning in Wollo University is not satisfactory. As the study indicated, there were many challenges hindering the implementation of cooperative learning in the University.

- From the discussion of the data, it is clear that lack of awareness about cooperative learning is one of the challenges for its implementation in Wollo University. In this regard, even some of the informants argued that cooperative learning has a negative impact on the academic status of students because as to them this method made many of the students to be dependent on the high achiever students. Another challenge that the study found out was the existence of poor coordination of group member contribution. In addition, it is confirmed that lack of experience in cooperative learning is a problem in practicing cooperative learning.

\section{Recommendations}

In order to improve the practice of cooperative learning, the writers forwarded the following recommendations.

$\Rightarrow$ As indicated in the findings of the research, many of the problems in the implementation of cooperative learning seemed to have emanated from lack of awareness about the merits of cooperative learning as well as knowledge gap how to implement cooperative learning. In order to solve this problem, concerning body of the University should facilitate short term trainings to be given for the instructors to fill this gap. In fact, instructors are expected to attend HDP thus many of them are certified with it. However, to update the knowledge gained by attending HDP, short term training could play significant contribution.

- From the findings of this study, a gap was identified about the students' commitment to actively engage in cooperative learning activities. To fill this gap, awareness creation training about benefits and principles of cooperative learning should be given for students of the university. The problem of lack of commitment is observed not only on students but also instructors. Thus, instructors and students should be committed to implement cooperative learning. Without their commitment, it would be difficult to make cooperative learning effective. Of course, the commitments of students and instructors may not be fruitful unless cooperative learning activities are fully and effectively supported by the University's administrative body. Therefore, the administrative body need to give due attention for the effective implementation of cooperative learning.

- A manual should be prepared by pedagogy professionals of the University concerning how to implement cooperative learning. The recommended short-term training both for students and instructors should be guided by this manual. A follow up system should be designed by the University's Quality Assurance Directorate to check the that both students and instructors perform their responsibilities in the implementation of cooperative learning. Instructors should distribute responsibilities for each group member to ensure equal sharing of role and avoid the burden customarily imposed on the group leaders. In addition, instructors should follow up whether each group member effectively accomplishes his/her own assigned role.

- To motivate students, it could be recommended that Departments should arrange experience sharing between groups which are less effective and successful in implementing cooperative learning. Experience sharing also should be facilitated for the instructors of the University. 


\section{References}

Alamawum Taye (2014). "An Evaluation of the Design of the Speaking Lessons in Grade 11 English Textbook in terms of Promoting Cooperative Learning: The case of Jigjiga Preparatory School.” MA Thesis, Haramaya University.

Amineh, Roya \& Asl, Hanieh (2015). Review of Constructivism and Social Constructivism. Journal of Social Sciences, Literature and Languages, 1(1), 9-16.

Aragaw Delele Endeshaw (2015). The Effect of Cooperative Learning on Students' EFL Reading Comprehension: Meshentie Grade Nine High School Students in Focus. Education Journal, 4(5), 222-231.

Blake, Barbara \& Pope, Tambra (2008). Developmental Psychology: Incorporating Piaget's and Vygotsky's Theories in Classrooms. Journal of Cross-Disciplinary Perspectives in Education, 1(1), 59 - 67.

Creswell, John W. (2014). Research Design: Qualitative, Quantitative and Mixed Methods Approach, $4^{\text {th }}$ Edition, Los Angeles: SAGE Publications, Inc.

Efrem Gulfo \& Oukula Obsa (2015). Students Attitude towards One-to-Five Peer Learning: A New Approach for Enhancing Education Quality in Wolaita Sodo University, Ethiopia. Journal of Education and Practice, 6 (19), 152-159.

Hagos Haftu (2012). “The Major Challenges of Implementing Active Learning in EFL Classes of Wolaita Sodo University" MA Thesis. Addis Ababa University.

Johnson, D., Johnson, R., \& Smith, A. (1998). Cooperative learning returns to college: what evidence is there that works?

Liang, Tsailing (2002). "Implementing Cooperative Learning in EFL Teaching: Process and Effects." Ph.D. Dissertation. National Taiwan Normal University. Graduate Institute of English.

Muhammad Kedir Hiko (2014). Cooperative Learning Practices in College of Education and Behavioral Sciences in Haramaya University, Ethiopia. International Journal of Science and Research (IJSR), 3 (11).

Neo, J (2005). Positive interdependence, academic and collaborative-skills group contingencies and isolated students. American Educational Research Journal, 23, 476-488.

Sayyed Rashid Shah (2013). Research Paradigms: Researchers' Worldviews, Theoretical Frameworks and Study Designs, Arab World English Journal, 4 (4), 252-264.

Slavin, R. (1996). Research on cooperative learning and achievement: what we know, what we need to know. Contemporary Educational Psychology, 21, 43-69.

Tavakol, Mohsen (2011). Making sense of Cronbach's alpha, International Journal of Medical Education, 2:5355.

Wang, Tzu-Pu (2009). Applying Slavin's Cooperative Learning Techniques to a College EFL Conversation Class. The Journal of Human Resource and Adult Learning, 5.

Yeabsira Kefale (2015). "Problems Affecting the Implementation of Cooperative Learning." MA Thesis, Addis Ababa University. 